Alagoas antwren Myrmotherula snowi, Fatu Hiva monarch Pomarea whitneyi), amphibians (dusky gopher frog $L i$ thobates sevosus, Houston toad Anaxyrus houstonensis, mountain chicken Leptodactylus fallax), fishes (estuarine pipefish Syngnathus watermeyeri, largetooth sawfish Pristis pristis), insects (Patagonian bumblebee Bombus dahlbomii, Poweshiek skipperling Oarisma poweshiek) and dipterocarp trees (Anisoptera reticulata, Vatica maritima) provided insights into the effectiveness of the tool across taxa, regions and biomes.

Preliminary Green List of Species metrics were produced for all 15 species, even those with limited data on abundance and distribution, and assessors made recommendations to improve assessment materials. Assessors found the tool useful and felt it addresses the identified need (Mallon \& Jackson, 2017, Oryx , 51, 605-609) to demonstrate conservation successes and incentivize donors.

The highest conservation legacy scores were for birds (African penguin, Fata Hivu monarch), for whom failure to conserve habitats would have resulted in possible extinction. Eleven species are reliant on conservation to maintain their status (conservation dependence $>0 \%$ ), of which eight (African manatee, northern sportive lemur, Sumatran rhino, dusky gopher frog, Houston toad, mountain chicken, largetooth sawfish, Poweshiek skipperling) would probably become extirpated in the wild if conservation actions were halted.

Conservation gains are expected for eight species, with planned field projects likely to help produce the largest improvements in the mountain chicken and northern sportive lemur. Seven species had o\% conservation gain, suggesting their status may not improve in 10 years or three generations, even with conservation. This does not mean funding is misplaced (all seven species had a legacy or dependence score $\geq 20 \%$, demonstrating the importance of conservation). Rather, low conservation gains reflected challenges associated with conserving species that have small populations surviving in pockets of former range (e.g. Sumatran rhino, Poweshiek skipperling), face multiple threats across wide ranges (e.g. African manatee), or reproduce slowly (trees). Finally, although it may not be observed in the short term, all 15 species have long-term recovery potential and therefore conservation could improve their status.

We conclude that the Green List of Species can be used on diverse plant and animal species, although further testing will provide greater insights into its applicability across taxa. Conservation agencies and donors such as the National Geographic Society can use the conservation dependence and conservation gain metrics to monitor the impact of certain types of projects, as long as they operate at large enough temporal and spatial scales to address key threats. Regardless of project scale, the tool could help value and incentivize conservation and could assist in developing a common vision for range-wide species recovery.
Our insights have been shared with the IUCN Species Conservation Success Task Force and will be used to enhance the Green List of Species standard and guidance materials. We are indebted to the 26 people who helped with the assessments; they will co-author scientific papers to provide further peer review of the methods. The testing process enhanced our understanding of the value and uses of the IUCN Green List of Species and will ensure the tool is adapted and improved to be relevant and applicable to as many species as possible.

P.J. STEPHENSON (® orcid.org/0000-0002-0087-466X)
IUCN SSC Species Monitoring Specialist Group, Gingins,
Switzerland. E-mail stephensonpj@gmail.com

Catherine Workman Research and Conservation Grants, National Geographic Society, Washington, DC, USA

MOLLY K. GRACE Department of Zoology, University of Oxford, UK

BARNEY LONG Global Wildlife Conservation, Washington, DC, USA

\section{Thailand holds its first Parks Congress}

In recent years Thailand has enjoyed a remarkable increase in protected area coverage. It now has 128 terrestrial National Parks, 26 Marine National Parks, 6o Wildlife Sanctuaries and 63 Non-hunting Areas. Managed by the Department of National Parks, Wildlife and Plant Conservation, these protected areas cover c. $23 \%$ of Thailand's territory. This substantial allocation of land, freshwater and sea is justified by the protected areas being managed to deliver multiple benefits to farmers, fishers, students, visitors, researchers, tourism agencies, and others.

To respond to this growing responsibility, the Department of National Parks, Wildlife and Plant Conservation organized its first Thailand Parks Congress during 15-17 September 2019. Organized by a team led by Dr. Songtam Suksawang, Director of the Department's National Parks Office, over 500 staff were joined by environmental, media and non-governmental conservation organizations to explore ways to apply modern management approaches to the protected areas. New mobile phone apps for visitors were demonstrated, along with electronic registration for popular National Parks. The National Parks are now all linked by the internet, and field staff have hand-held management systems that facilitate patrolling, reporting and resource management. Aerial drones were demonstrated that are now patrolling the large protected areas to support efforts to limit encroachment and poaching. Congress participants were introduced to a system under development 
that will provide online booking for visits to National Parks, including lodging, transport, guides, special sites, and elephant safaris.

Thailand's protected areas are generally effective at curtailing deforestation within their boundaries, but continuing conversion of forests into plantations in areas surrounding some of the protected areas is isolating them as islands in a sea of agriculture. Such areas may be too small to support all species that occupied the larger landscape before it became fragmented, and the Congress gave significant attention to this issue. To promote landscape connectivity the Department of National Parks, Wildlife and Plant Conservation has adopted the concept of Forest Complexes, in which a collection of National Parks, Wildlife Sanctuaries and Non-hunting Areas can be linked to form a larger area that supports viable populations of wide-ranging species such as elephants, tigers, gaur and hornbills, and contributes to regional social and economic development through provision of ecosystem services. Conservation corridors can include buffer zones, lands managed by government agencies other than the Department, and private lands. Presentations showed how these corridors can expand the effective size of protected areas to enhance their ecological value. Discussions also highlighted management of potential negative ecological impacts of connectivity, such as the the spread of disease, invasive alien species, forest fires and other natural hazards.

New legislation for Thailand's protected areas was approved in May 2019 and will have entered into force in November 2019, and was discussed in detail, to prepare site managers for its implementation. Highlights include encouraging research that supports more effective management of protected areas and building understanding of difficult issues such as collecting of voucher specimens, samples of genetic materials for laboratory studies, photographic documentation and intellectual property rights.

Climate change affects all parts of Thailand's national economy and is a major policy concern. The Congress heard that the role of National Parks is critical but needs to be given more attention. For example, National Parks may store more carbon than the rest of the country combined, judging from the biomass of the mature forests and coral reefs they protect; the coastal National Parks provide protection from extreme climatic events; and many of the National Parks support generation of hydroelectricity, a sustainable form of energy. Perhaps most importantly, the great diversity of the natural ecosystems in the protected areas provides nature's capacity for adapting to the changing environmental conditions that will surely come from global warming. The Department of National Parks, Wildlife and Plant Conservation was challenged to become a more important part of developing national policies for mitigating the impacts of climate change and adapting to the new conditions as they emerge. The Thailand Parks Congress was an opportunity for introspection as the Department seeks to manage the protected areas to an international standard so they can play their proper role in global efforts to implement sustainable forms of development in balance with nature.

Jeffrey A. McNeely Policy Liaison for the Society for Conservation Biology.E-mail jeffmcneely2@gmail.com

\section{Illegal trade in Indonesia's National Rare Animal has moved online}

Despite all native diurnal birds of prey having been included on Indonesia's protected species list in 1970, raptors have continued to be offered openly for sale in the country's many bird markets. The buying and selling, and also the keeping, of protected wildlife in Indonesia is a crime, punishable by up to 5 years imprisonment and/or a fine of c. USD 7,000. In 1993 the Javan hawk-eagle Nisaetus bartelsi was declared Indonesia's National Rare Animal (Satwa Langka Nasional); it has an estimated population size of $600-900$ and is categorized as Endangered on the IUCN Red List. The species is a clear K-strategist: females start breeding when c. 4 years old, lay only a single egg per clutch and only breed every 2 years. In 2009 we reported on the trade in Javan hawk-eagles, based on c. 250 surveys of bird markets during 1979-2007 (Nijman et al., Oryx, $43,122-128)$ and recorded an increase in the number of individuals for sale following the rise of the species' profile in 1993.

During the last 5 years my colleagues and I have made c. 500 visits to bird markets in Indonesia, including to all bird markets where we observed Javan hawk-eagles previously. Compared to the 1990s and 2000s, we saw fewer birds of prey in these markets and did not record any Javan hawk-eagles. It is clear, however, that the trade in Javan hawk-eagles has not diminished, but has moved online (Iqbal, 2016, BirdingAsia, 25, 30-35; Gunawan et al., 2017, Kukila, 20, 1-10).

In August 2019 I checked nine Indonesian Facebook groups that specialize in trading raptors; the groups have unambiguous names such as Selling and Buying of Eagles and Falcons (Jual Beli Elang dan Alap-alap). All were based in Java and were public, with the posts visible even without Facebook membership. I recorded 514 diurnal birds of prey of 21 species for sale (all verified by posted photographs or short videos). This included 12 Javan hawkeagles, one adult Blyth's hawk-eagle Nisaetus alboniger (advertized as a Javan hawk-eagle), two adult Sulawesi hawk-eagles Nisaetus lanceolatus and 69 changeable hawkeagles Nisaetus cirrhatus (48 adults or subadults). All the Javan hawk-eagles were young (five chicks, five firstyear birds, two immatures $<_{3}$ years old). There were no 